\title{
24. MAJOR- AND TRACE-ELEMENT GEOCHEMISTRY OF BASALTS FROM ŌJIN, NINTOKU, AND SUIKO SEAMOUNTS OF THE EMPEROR SEAMOUNT CHAIN: DSDP-IPOD LEG 55
}

\author{
A. E. Bence, Department of Earth and Space Sciences, State University of New York, Stony Brook, New York \\ S. R. Taylor, Research School of Earth Sciences, Australian National University, Canberra, ACT Australia \\ and \\ M. Fisk, Department of Earth and Space Sciences, State University of New York, Stony Brook, New York
}

\begin{abstract}
Alkali series and tholeiitic basalts from Ōjin, Nintoku, and Suiko Seamounts of the Emperor Seamount chain are very similar in their major and LIL (large-ion lithophile) trace-element chemistry to the alkaline and tholeiitic basalts erupted on the island of Hawaii. They are characterized by high total content of alkalis, high $\mathrm{TiO}_{2}$ and " $\mathrm{FeO}$ " contents, low $\mathrm{Al}_{2} \mathrm{O}_{3}$ contents, and low $\mathrm{Mg} /\left(\mathrm{Mg}+\mathrm{Fe}^{2+}\right)$ relative to mid-ocean ridge basalts (MORBs). LIL element abundances in one tholeiite from Ōjin Seamount are enriched by factors of 5 to 10 relative to MORBs. REE (rare-earth element) patterns in all the samples are highly fractionated; the heavy rare-earth elements (HREE) are depleted markedly. This is consistent with residual garnet in the source regions. LIL element variations among the seamount basalts suggest variable degrees of partial melting. Olivine fractionation, presumably in a shallow magma chamber, accounts for some of the intrasite major-element compositional variations. There are between the seamount basalts and those from the island of Hawaii no systematic differences that might be attributed to the temporal evolution of a single hot-spot source.
\end{abstract}

\section{INTRODUCTION}

Basalts from three seamounts in the Emperor Seamount chain (Ōjin, Hole 430A; Nintoku, Hole 432A; Suiko, Holes 433A, 433B, 433C) were recovered by drilling during DSDP-IPOD Leg 55. The principal objective of Leg 55 geochemistry studies was to determine how the chemistry of basalts generated by one hot spot evolve with time. If the hot-spot hypothesis (see, for example, Jackson, 1977) is correct, basalts erupted along the Emperor-Hawaiian chain were generated at a single hot spot over a period of about 70 m.y.

For this preliminary report, we have analyzed selected alkalic and tholeiitic basalts from each of the three seamounts for the major elements, for rare earths, and for $\mathrm{Cs}, \mathrm{Ba}, \mathrm{Pb}, \mathrm{Th}, \mathrm{U}, \mathrm{Zr}, \mathrm{Hf}, \mathrm{Nb}, \mathrm{Sn}$, and Mo. Comparison of the trace-element data for the various drill sites, and comparison of these data with data reported for Hawaiian basalts of comparable major-element chemistry, may allow us to evaluate the temporal evolution of the hot-spot process and the mechanisms of magma genesis and evolution.

Major-element abundances (Table 1) were determined by electron probe microanalysis of powders fused on an iridium strip furnace (Nicholls, 1974). USGS standard basalts prepared and analyzed in the same manner were used to monitor the analyses. Analyses were obtained in real time on an automated 4-spectrometer ARL-EMX-SM electron microprobe. Data reduction procedures are those of Bence and Albee (1968). Trace-element abundances (Tables 2 and 3) were determined at the Australian National University by spark source mass spectrometry, using the techniques of Taylor and Gorton (1976).

\section{RESULTS}

\section{Major-Element Chemistry}

All the basalts studied for this report have major-, minor-, and trace-element chemistries similar to those of the alkalic series-tholeiitic basalt sequences erupted on the island of Hawaii. It is therefore useful to use the compositional fields defined by the Hawaiian basalts in discussions of the chemistries of the Ōjin, Nintoku, and Suiko seamount basalts. In these discussions we have arbitrarily used the presence or absence of normative hypersthene as the criterion for calling a basalt alkalic or tholeiitic. In at least one instance, this results in classification of a basalt (Sample 432A-2-1, 86-96 cm) as a tholeiite, even though in all other respects it has transitional or alkaline affinities.

\section{Hole 430A: Ōjin Seamount}

The upper three flows of Hole 430A are slightly nepheline-normative (columns 1, 2, and 3, Table 1) and are characterized by low $\mathrm{CaO}$ contents $(6.75$ to $7.43 \mathrm{wt}$ $\%$ ), high $\mathrm{Na}_{2} \mathrm{O}$ contents (4.31 to 4.51 wt. \%), and high $\mathrm{K}_{2} \mathrm{O}$ contents (1.57 to $1.71 \mathrm{wt} . \%$ ) relative to the alkalic 
TABLE 1

Major-Element Chemistry of Basalts from Ōjin, Nintoku, and Suiko Seamounts (data in wt. \%)

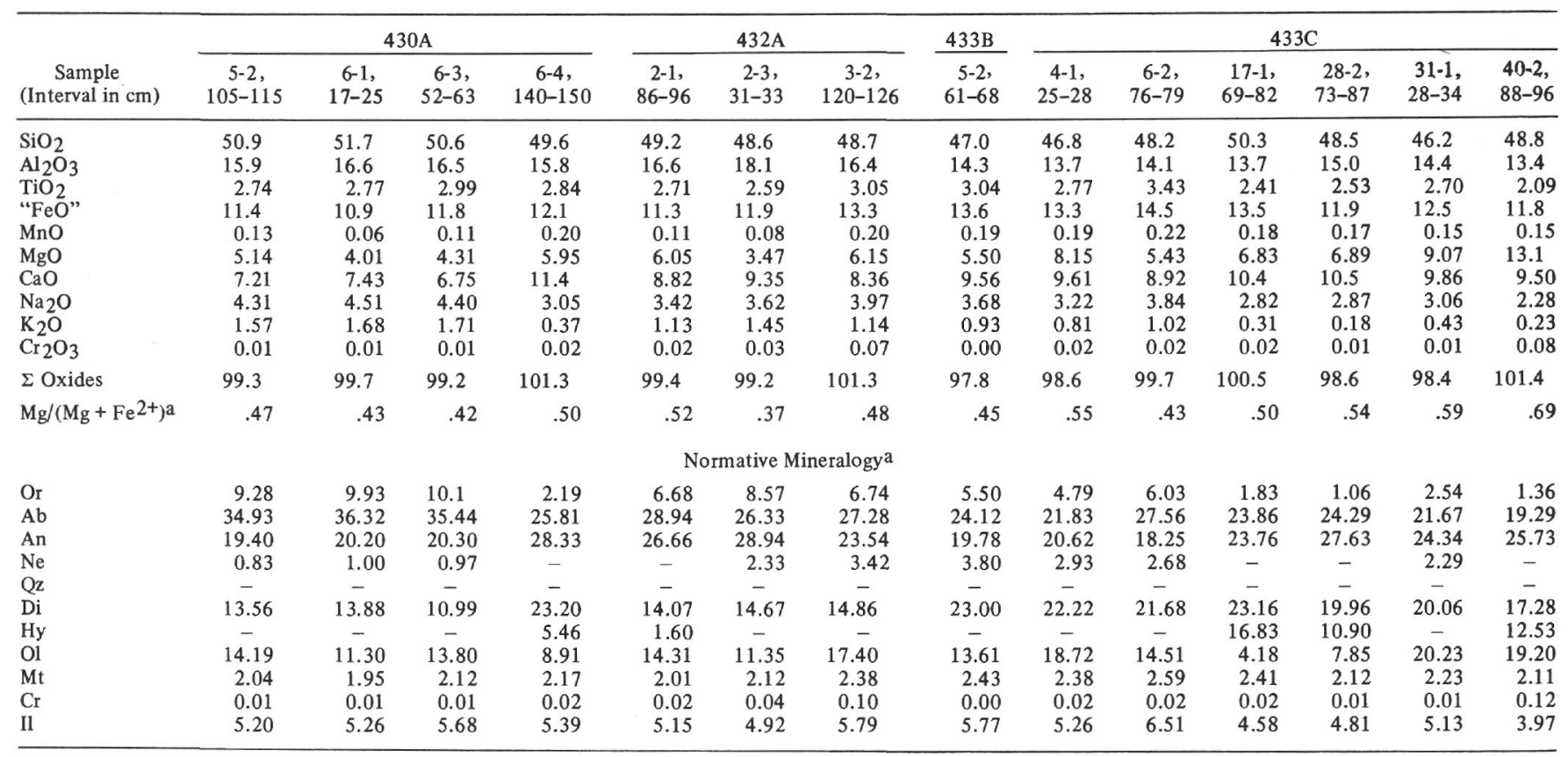

${ }^{\mathrm{a}}$ Calculated for $\mathrm{Fe}^{3+} / \Sigma \mathrm{Fe}=0.1$ (atomic).

TABLE 2

Rare-Earth Data (ppm) for Basalts from $\bar{O}$ jin, Nintoku, and Suiko Seamounts

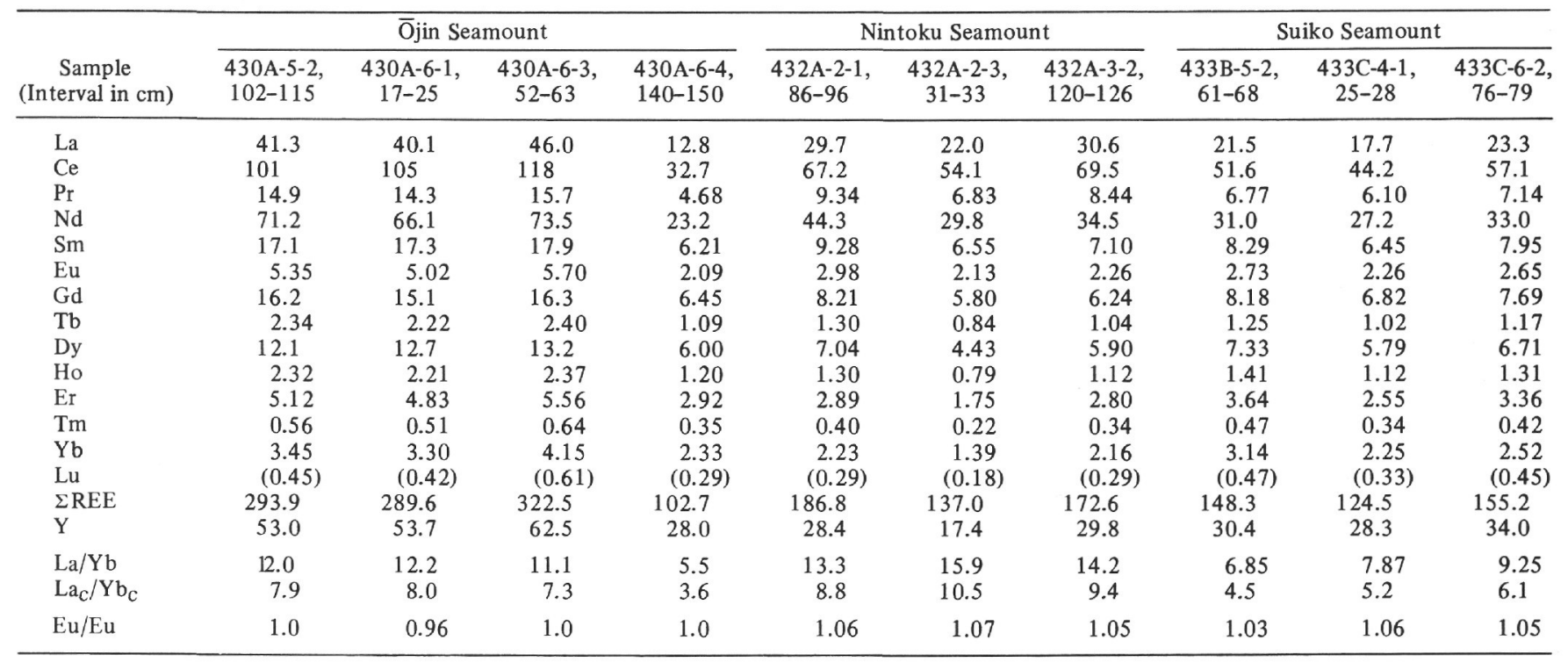

basalts from Nintoku and Suiko Seamounts. They plot in the alkali field of the $\mathrm{Na}_{2} \mathrm{O}+\mathrm{K}_{2} \mathrm{O}$ versus $\mathrm{SiO}_{2}$ diagram for Hawaiian basalts (Figure 1). The Ōjin alkalic basalts are also similar to the Hawaiian alkalic basalts, in that they lie on the Hawaiian alkali-differentiation trend (Figure 2a). Low $\mathrm{Mg} /\left(\mathrm{Mg}+\mathrm{Fe}^{2+}\right)$, low $\mathrm{MgO}$ content, and high $\mathrm{Al}_{2} \mathrm{O}_{3}$ content (Figure 3) are consistent with a petrogenesis involving significant differentiation through olivine fractionation. The Ōjin alkali basalts are enriched in $\mathrm{SiO}_{2}$ and depleted in $\mathrm{CaO}$, and have comparable concentrations of $\mathrm{TiO}_{2}$ (Figure 4),
$\mathrm{Al}_{2} \mathrm{O}_{3}$, and " $\mathrm{FeO}$ " relative to alkali basalts from Kohala, Mauna Kea, and Hualalai volcanoes on the island of Hawaii.

One hypersthene-normative basalt was sampled below the alkali basalts on Ōjin Seamount. This basalt (Sample 430A-6-4, 140-150 cm) plots in the tholeiite field of Hawaiian basalts (Figure 5), and is similar to the hypersthene-normative basalts from Suiko Seamount. It falls along the tholeiite differentiation trend for Hawaiian basalts on an AFM diagram (Figure 2a), but may be distinguished from Hawaiian tholeiites by its higher 
TABLE 3

Selected Trace Elements (ppm) for Basalts from $\overline{0}$ jin, Nintoku, and Suiko Seamounts

\begin{tabular}{|c|c|c|c|c|c|c|c|c|c|c|}
\hline \multirow[b]{2}{*}{$\begin{array}{c}\text { Sample } \\
\text { (Interval in } \mathrm{cm} \text { ) }\end{array}$} & \multicolumn{4}{|c|}{ Ōjin Seamount } & \multicolumn{3}{|c|}{ Nintoku Seamount } & \multicolumn{3}{|c|}{ Suiko Seamount } \\
\hline & $\begin{array}{l}430 \mathrm{~A}-5-2 \\
102-105\end{array}$ & $\begin{array}{c}430 \mathrm{~A}-6-1 \\
17-25\end{array}$ & $\begin{array}{c}430 A-6-3 \\
52-63\end{array}$ & $\begin{array}{c}430 \mathrm{~A}-6-4 \\
140-150\end{array}$ & $\begin{array}{c}432 \mathrm{~A}-2-1 \\
86-96\end{array}$ & $\begin{array}{c}432 \mathrm{~A}-2-3 \\
31-33\end{array}$ & $\begin{array}{c}432 \mathrm{~A}-3-2 \\
120-126\end{array}$ & $\begin{array}{c}433 B-5-2 \\
61-68\end{array}$ & $\begin{array}{c}433 C-4-1 \\
25-28\end{array}$ & $\begin{array}{c}433 \mathrm{C}-6-2, \\
76-79\end{array}$ \\
\hline $\mathrm{K}($ per cent) & 1.33 & 1.38 & 1.44 & 0.30 & 0.79 & 1.06 & 0.99 & 0.71 & 0.66 & - \\
\hline 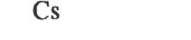 & 0.14 & 0.09 & 0.14 & 0.04 & 0.12 & 0.46 & 0.14 & 0.13 & 0.08 & 0.10 \\
\hline $\begin{array}{l}\mathrm{Ba} \\
\mathrm{K} / \mathrm{Ba} \\
\mathrm{Pb}\end{array}$ & $\begin{array}{l}385 \\
35 \\
3.78\end{array}$ & $\begin{array}{c}330 \\
42 \\
3.78\end{array}$ & $\begin{array}{c}390 \\
37 \\
4.8\end{array}$ & $\begin{array}{c}125 \\
24 \\
1.4\end{array}$ & $\begin{array}{l}305 \\
26 \\
2.55\end{array}$ & $\begin{array}{c}330 \\
32 \\
2.33\end{array}$ & $\begin{array}{l}410 \\
24 \\
2.45\end{array}$ & $\begin{array}{l}230 \\
31 \\
2.72\end{array}$ & $\begin{array}{c}205 \\
32 \\
1.66\end{array}$ & $\begin{array}{l}265 \\
- \\
1.95\end{array}$ \\
\hline $\begin{array}{l}\text { Th } \\
\text { U } \\
\text { Th/U }\end{array}$ & $\begin{array}{l}3.23 \\
1.02 \\
3.18\end{array}$ & $\begin{array}{l}3.31 \\
1.13 \\
2.92\end{array}$ & $\begin{array}{l}3.74 \\
1.19 \\
3.16\end{array}$ & $\begin{array}{l}1.06 \\
0.38 \\
2.80\end{array}$ & $\begin{array}{l}2.35 \\
0.74 \\
3.18\end{array}$ & $\begin{array}{l}2.33 \\
0.62 \\
3.78\end{array}$ & $\begin{array}{l}2.61 \\
0.81 \\
3.23\end{array}$ & $\begin{array}{l}1.81 \\
0.68 \\
2.67\end{array}$ & $\begin{array}{l}1.58 \\
0.51 \\
3.10\end{array}$ & $\begin{array}{l}1.86 \\
0.51 \\
3.65\end{array}$ \\
\hline $\begin{array}{l}\mathrm{Zr} \\
\mathrm{Hf} \\
\mathrm{Zr} / \mathrm{Hf}\end{array}$ & $\begin{array}{c}450 \\
11.0 \\
41\end{array}$ & $\begin{array}{l}420 \\
11.1 \\
38\end{array}$ & $\begin{array}{l}500 \\
12.3 \\
41\end{array}$ & $\begin{array}{c}143 \\
4.59 \\
31\end{array}$ & $\begin{array}{c}192 \\
6.2 \\
31\end{array}$ & $\begin{array}{c}127 \\
3.9 \\
33\end{array}$ & $\begin{array}{c}202 \\
5.2 \\
39\end{array}$ & $\begin{array}{c}186 \\
5.3 \\
35\end{array}$ & $\begin{array}{c}175 \\
4.4 \\
39\end{array}$ & $\begin{array}{c}215 \\
5.5 \\
39\end{array}$ \\
\hline $\begin{array}{l}\mathrm{Nb} \\
\mathrm{Zr} / \mathrm{Nb}\end{array}$ & $\begin{array}{l}45.4 \\
10\end{array}$ & $\begin{array}{l}48 \\
8.7\end{array}$ & $\begin{array}{l}51 \\
9.7\end{array}$ & $\begin{array}{r}14.7 \\
9.7\end{array}$ & $\begin{array}{r}29.4 \\
6.5\end{array}$ & $\begin{array}{r}29.5 \\
4.3\end{array}$ & $\begin{array}{r}41.6 \\
4.9\end{array}$ & $\begin{array}{r}25.7 \\
7.2\end{array}$ & $\begin{array}{r}22.6 \\
7.7\end{array}$ & $\begin{array}{r}30.2 \\
7.2\end{array}$ \\
\hline $\begin{array}{l}\text { Sn } \\
\text { Mo }\end{array}$ & $\begin{array}{l}3.0 \\
1.7\end{array}$ & $\begin{array}{l}3.9 \\
1.6\end{array}$ & $\begin{array}{l}4.1 \\
1.9\end{array}$ & $\begin{array}{l}1.6 \\
0.7\end{array}$ & $\begin{array}{l}2.3 \\
1.4\end{array}$ & $\begin{array}{l}1.7 \\
1.3\end{array}$ & $\begin{array}{l}2.0 \\
1.7\end{array}$ & $\begin{array}{l}2.3 \\
1.5\end{array}$ & $\begin{array}{l}2.0 \\
1.3\end{array}$ & $\begin{array}{l}2.2 \\
1.4\end{array}$ \\
\hline
\end{tabular}

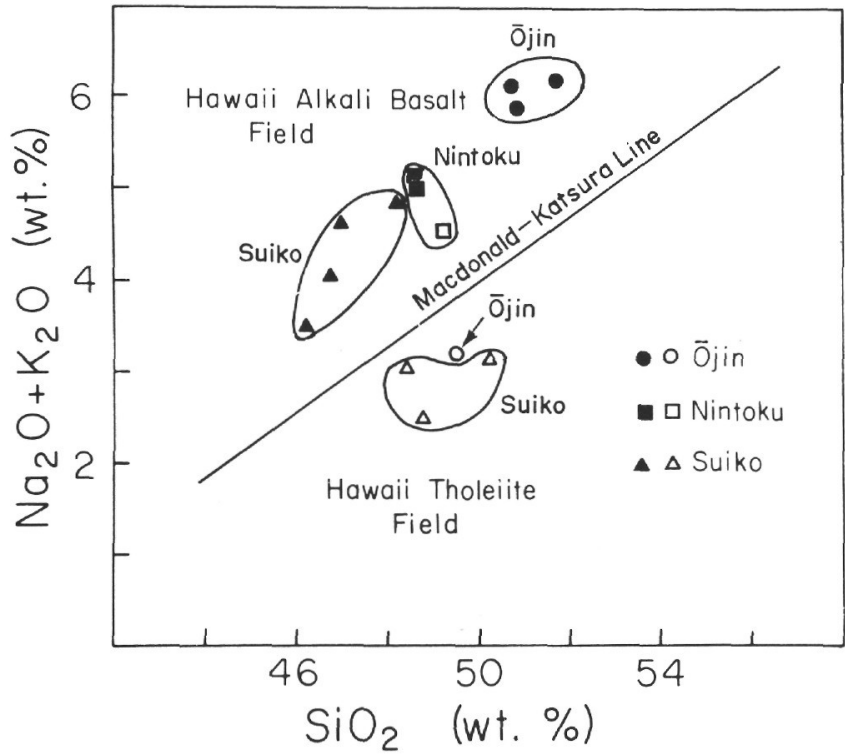

Figure 1. Total alkalis versus silica for basalts from Ojin, Nintoku, and Suiko seamounts, after Macdonald and Katsura (1964), whose line separates the Hawaiian alkali series basalts and tholeiitic basalts. Open symbols are hypersthene-normative samples. Closed symbols are nepheline-normative.

$\mathrm{Al}_{2} \mathrm{O}_{3}$ and $\mathrm{CaO}$ contents. The $\mathrm{REE}$ and large-ion lithophile (LIL) element data, described below, confirm its tholeiitic character.

\section{Hole 432A: Nintoku Seamount}

Three flow units from Nintoku Seamount were sampled. Two are nepheline-normative, and the third (Sample 432A-2-1, 86-96 cm) is slightly $(1.6 \%)$ hypersthene-normative (Table 1). The alkalic basalts at Nintoku contain less $\mathrm{SiO}_{2}$ and $\mathrm{Na}_{2} \mathrm{O}$ but more $\mathrm{CaO}$ than the Ōjin alkalic basalts. This is reflected in higher normative anorthite and nepheline and lower normative albite values. Total normative plagioclase is comparable in the two suites.

The hypersthene-normative sample is distinguished from the alkali basalts only by its higher $\mathrm{SiO}_{2}$ content. We suggest that it is an alkali basalt with slightly tholeiitic affinities. It plots in the alkali basalt field of Hawaiian basalts (Figure 1), and also plots on the alkali basalt differentiation trend of Hawaii (Figure 2b). Furthermore, its LIL trace-element abundances are similar to those of Hawaiian alkali basalts and to the alkaline basalts from Ōjin and Suiko seamounts.

\section{Holes 433B and 433C: Suiko Seamount}

As on Ōjin and Nintoku Seamounts, the upper flow units of Suiko Seamount are alkalic, and occasionally some of the deeper flows are also alkalic. The alkali basalts are similar to those from Hawaii, but contain lower concentrations of total alkalis, alumina, and silica and higher concentrations of " $\mathrm{FeO}$ " than the alkali basalts from Ōjin and Nintoku (Figure 1). They are nephelinenormative ( 3 to $4 \%$ ) and follow the alkaline differentiation trend in Hawaiian basalts (Figure 2c). The one alkali basalt that we analyzed from deep in the seamount (Sample 433C-31-1, 28-34 cm) is lower in total alkali concentration and higher in $\mathrm{MgO}$ concentration than the three alkali flows at the surface of the seamount.

The hypersthene-normative flows from Suiko Seamount are similar to Hawaiian tholeiites and to the one hypersthene-normative basalt from Ōjin Seamount (Figure 1). These Suiko tholeiites fall on the Hawaiian tholeiite differentiation trend of Macdonald and Katsura (1964) (Figure 2c), and suggest olivine fractionation as a means of deriving these basalts from the same or a similar parental magma.

\section{Trace Elements}

\section{Hole 430A: Ōjin Seamount}

Tholeiitic basalt Sample 430A-6-4, 140-150 cm has a rare-earth pattern and overall REE abundance levels 
(a)
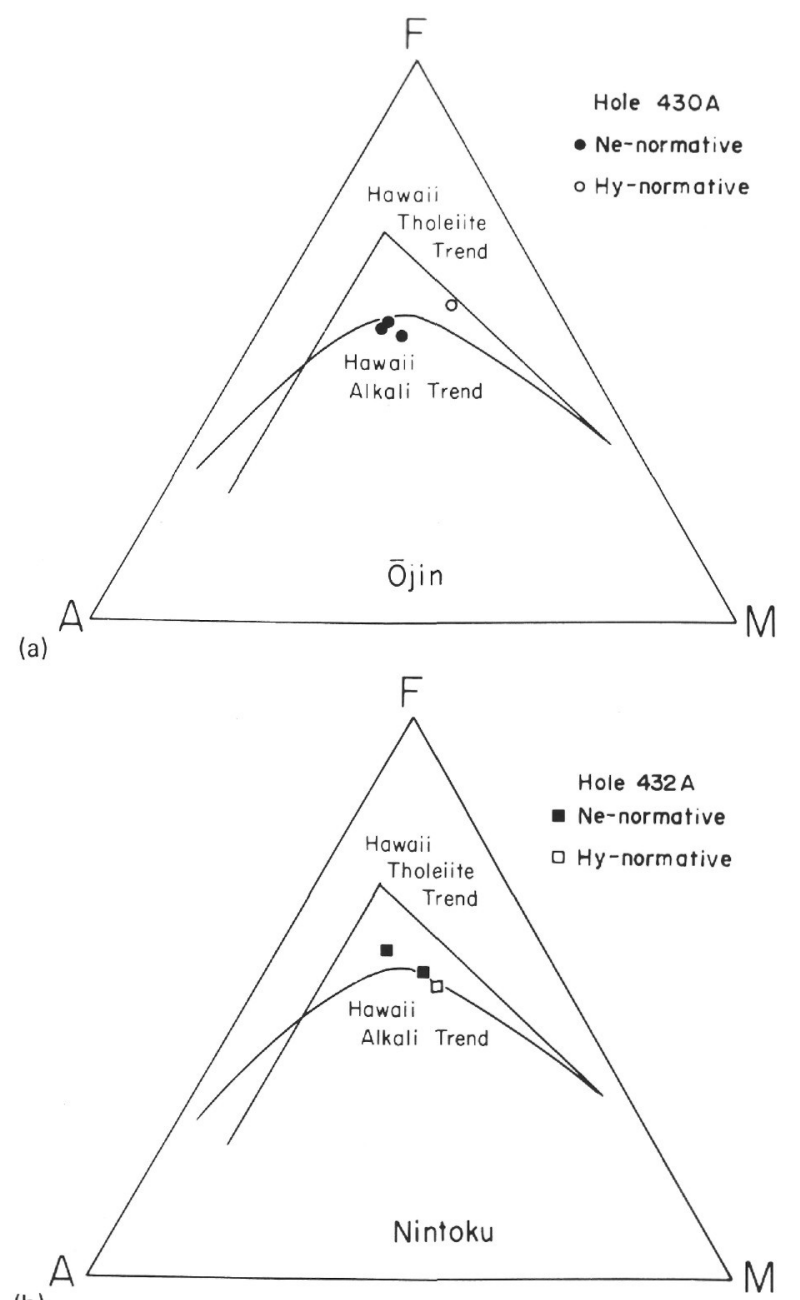

(b)

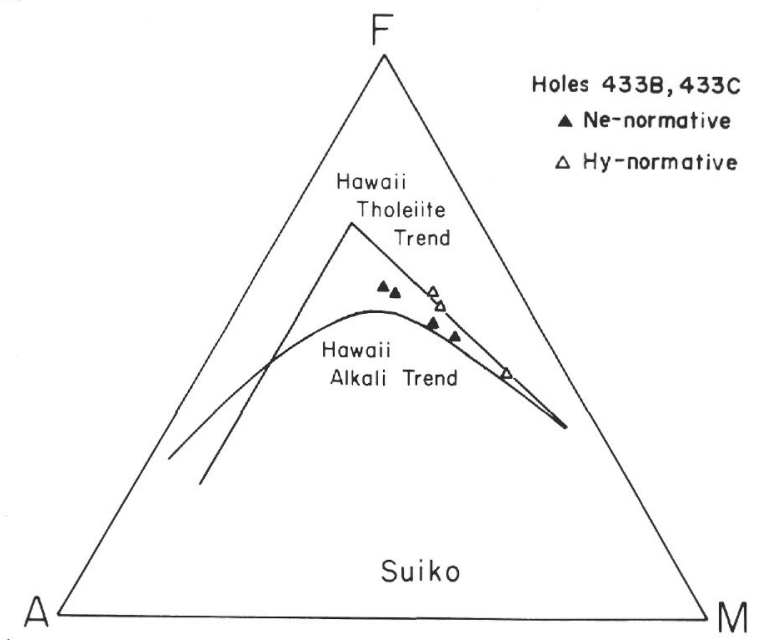

(c)

Figure 2. (a) AFM ternary diagram for four flows from Hole 430A, Ojin Seamount. A is $\mathrm{Na}_{2} \mathrm{O}+\mathrm{K}_{2} \mathrm{O}$ (wt. \%). $\mathrm{F}$ is $\mathrm{Fe}^{2+}$ and $\mathrm{Fe}^{3+}$ recalculated as $\mathrm{FeO}$ (wt. \%), and $\mathrm{M}$ is $\mathrm{MgO}$ (wt. \%). The Hawaiian tholeitic and alkali differentiation trends of Macdonald and Katsura (1964) are shown for comparison. (b) AFM ternary diagram for Hole $432 A$, Nintoku Seamount. (c) AFM ternary diagram for Holes $433 B$ and $433 C$, Suiko Seamount.
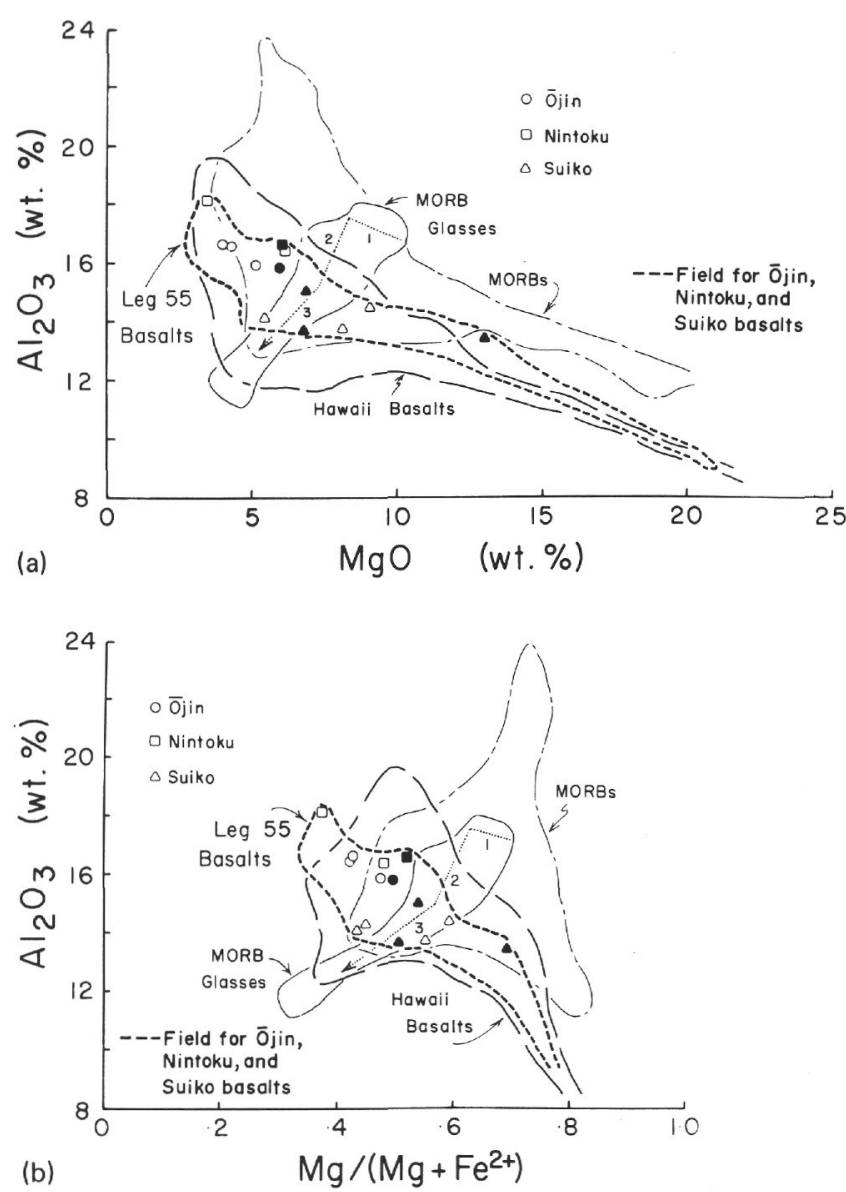

Figure 3. $\mathrm{Al}_{2} \mathrm{O}_{3}$ versus $\mathrm{MgO}$ variations in Ojin, Nintoku, and Suiko basalts. Open symbols: nephelinenormative compositions. Closed symbols: hypersthene-normative compositions. Fields for Hawaii basalts, MORB crystalline basalts, and MORB glasses are shown. MORB glass field defines the liquid line of descent (from high to low $\mathrm{MgO}$ ) as shown by the arrow. Liquids are first saturated with olivine ( \pm spinel) (1), olivine + plagioclase (2), and finally olivine + plagioclase + clinopyroxene (3). Field for Öjin, Nintoku, and Suiko Seamounts from Clague et al. (this volume). (b) $\mathrm{Al}_{2} \mathrm{O}_{3}$ versus $\mathrm{Mg} /(\mathrm{Mg}$ $+\mathrm{Fe}^{2+}$ ) variations in Ojjin, Nintoku, and Suiko seamounts. Symbols and Fields as for Figure $3 a . M g /(M g$ $+\mathrm{Fe}^{2+}$ ) calculated assuming $\mathrm{Fe}^{3+} /$ total $\mathrm{Fe}=0.1$ (atomic).

comparable to those of Mauna Loa summit basalts (Figure 6, Table 2) (Leeman et al., 1977; L. Haskin, personal communication). These basalts have a distinctive flat light rare-earth (LREE) pattern with LREE abundance levels between 20 and 40 times chondritic abundances. The Ōjin tholeiite is not quite as depleted in the light rare-earth elements (LREE) as the Mauna Loa summit basalts; but this difference does not appear to be significant. The REE patterns in both the Hawaiian and Ojin tholeiites contrast markedly with typical midocean ridge basalts (MORBs), which characteristically are depleted in the LREE and have flat HREE at about 


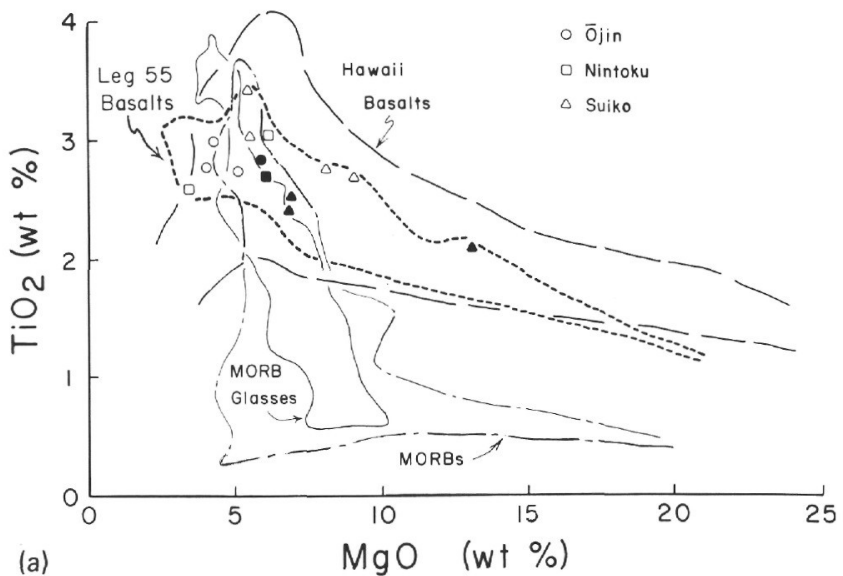

(a)

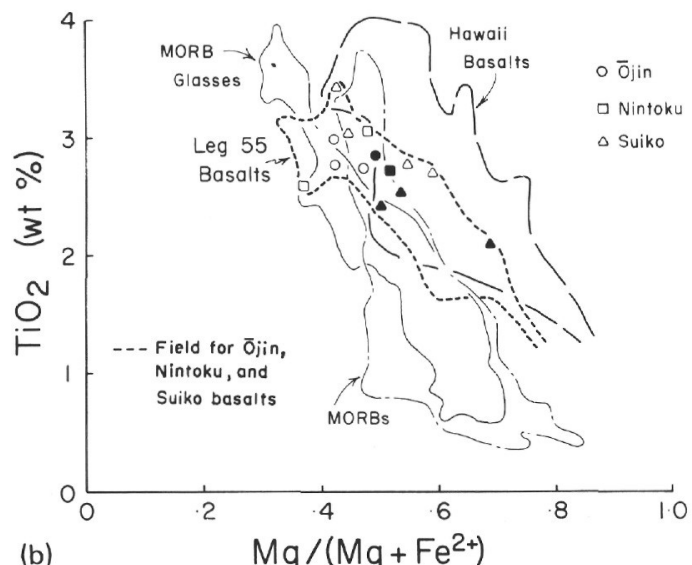

(b)

Figure 4. (a) $\mathrm{TiO}_{2}$ versus $\mathrm{MgO}$ variations in Ōjin, Nintoku, and Suiko basalts. Symbols and fields as for Figure 3a. (b) $\mathrm{TiO}_{2}$ versus $\mathrm{Mg} /\left(\mathrm{Mg}+\mathrm{Fe}^{2+}\right)$ variations in Ojin, Nintoku, and Suiko basalts. Symbols and fields as for Figure $3 a$.

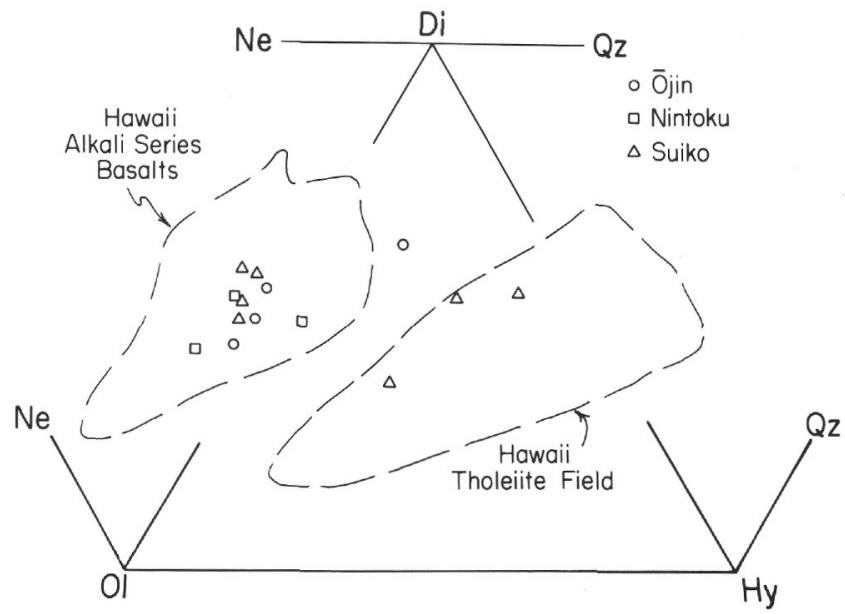

Figure 5. Projection from plagioclase of the normative chemistry of Ojin, Nintoku, and Suiko basalts.

10 to 20 times chondrites. REE patterns similar to those of $\bar{O}$ jin and Hawaii tholeiites occur in the high-K tholeiites obtained from topographic highs by the Deep

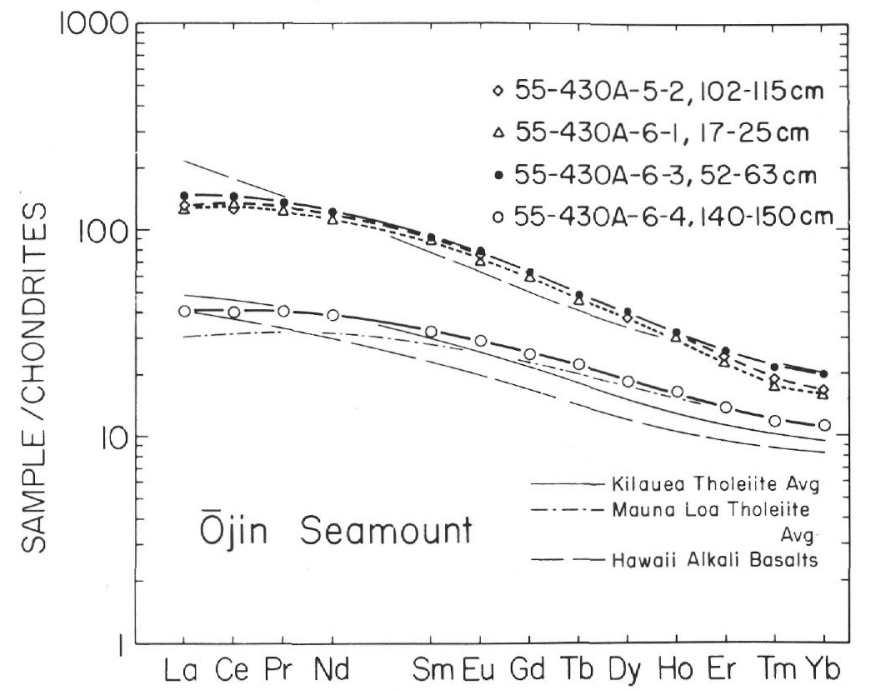

Figure 6. Normalized rare-earth element (REE) abundances for Ojin alkalic basalts and one tholeiite. Normalizing values are those of Taylor and Gorton (1977). Fields for Hawaii alkali series basalts (using data from Schilling and Winchester [1969] and Kay and Gast [1973]) and for average Mauna Loa and Kilauea summit tholeiites (after Leeman et al. [1977]) are shown.

Sea Drilling Project (see, for example, Frey et al., 1974; Bence et al., 1975).

The three alkali basalts analyzed have REE patterns identical to tholeiite Sample 430A-6-4, 140-150 cm, and are comparable to those of the Hawaiian alkali series basalts (Schilling and Winchester, 1969; Kay and Gast, 1973; L. Haskin, personal communication; Figure 6). The striking similarity in REE patterns of the tholeiite and alkali basalts from Nintoku Seamount is unusual. The abundance differences (a factor of 3 in the LREE and a factor of 1.5 to 2 in the HREE) and the pronounced HREE depletion could be a consequence of differing degrees of partial melting of a common source in which garnet is a residual phase. Fractionation of a common parent magma cannot produce the observed major- and trace-element characteristics.

The abundances of the other LIL elements $(K, C s$, $\mathrm{Ba}, \mathrm{Pb}, \mathrm{Th}, \mathrm{U}, \mathrm{Zr}, \mathrm{Hf}, \mathrm{Nb}$, etc.; Table 3) in tholeiite Sample 430A-6-4, 140-150 cm are lower by factors of 3 to 4 than in the alkaline basalts at Ōjin Seamount, but are comparable to their abundances in the tholeiites from Mauna Loa and Kilauea volcanoes. Abundances and abundance ratios of LIL elements in the Ōjin alkali series basalts are comparable to those observed in the alkali basalts from Kohala, Mauna Loa, and Haulalai volcanoes. Further, the $\mathrm{Zr} / \mathrm{Nb}$ ratio for the $\overline{\mathrm{O} j i n}$ basalts (average 9.5) is within the range of typical oceanic island values, and is at the low end of the range of MidAtlantic Ridge tholeiites (Erlank and Kable, 1976).

\section{Hole 432A: Nintoku Seamount}

The REE patterns for the three basalts analyzed are similar, and closely resemble those for the Hawaiian 
alkali series basalts (Kay and Gast, 1973; L. Haskin, personal communication). These patterns (Figure 7) differ from those of the Ōjin alkali basalts in that they are more linear, more depleted in the HREE, and have higher $\mathrm{La} / \mathrm{Sm}$ ratios. Garnet may be a more important residual phase in the source region of the Nintoku basalts than in the source region of the Ōjin alkali basalts.

In most aspects, the LIL element chemistry of these basalts is similar to that of alkali basalt from Ōjin Seamount; but the $\mathrm{Zr} / \mathrm{Nb}$ ratio is distinctly lower in the Nintoku samples (average 5.2).

The LIL element chemistry of hypersthene-normative sample 432-2-1, 86-96 cm is indistinguishable from that of the nepheline-normative basalts from Nintoku (Figure 7; Table 3).

\section{Site 433: Suiko Seamount}

The three Suiko samples for which trace elements were determined are alkali series basalts. Their REE patterns, characterized by flat LREE and depleted HREE, are most similar to the alkali basalts from Ōjin; but the overall REE abundances are lower by a factor of 2 in the Suiko basalt (Figure 8, Table 2). In this respect, the Suiko samples are more comparable to the alkaline basalts from Hawaii, but with a slightly flatter LREE pattern. It is interesting that the Suiko alkali basalt REE patterns are identical to the average Kilauea summit tholeiite reported by Leeman et al. (1977). The K/Ba and $\mathrm{Zr} / \mathrm{Nb}$ ratios (Table 3 ) are again within the range for ocean island basalts. The average $\mathrm{Zr} / \mathrm{Nb}$ ratio (7.4) for Suiko is intermediate between that of Ōjin and Nintoku.

\section{DISCUSSION}

Variation in abundances of the major and minor elements in the basalts at each site can be attributed largely to olivine fractionation. Low-pressure fractiona-

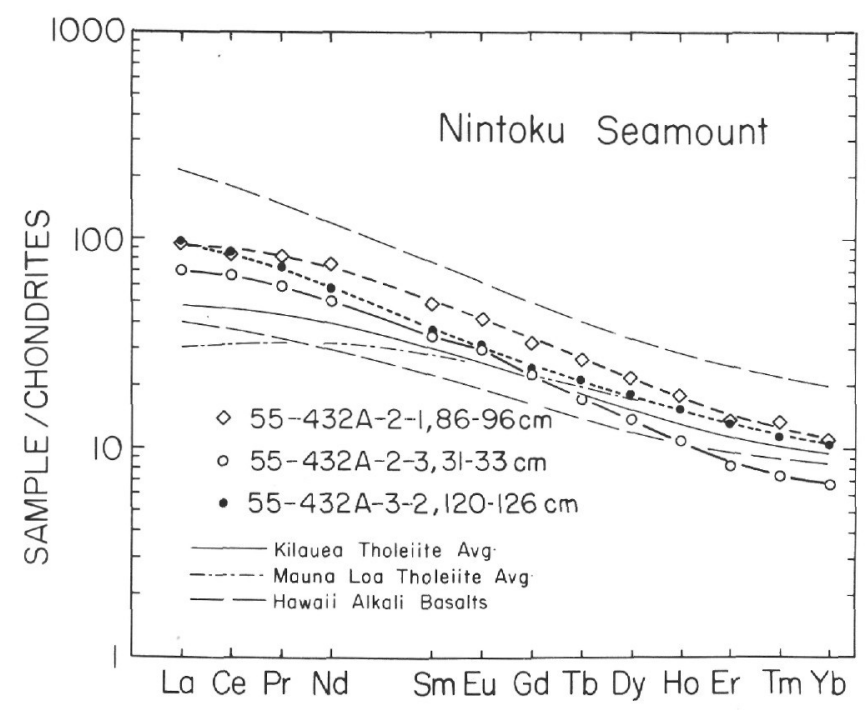

Figure 7. Normalized REE data for Nintoku Seamount basalts. Hawaii data as for Figure 6.

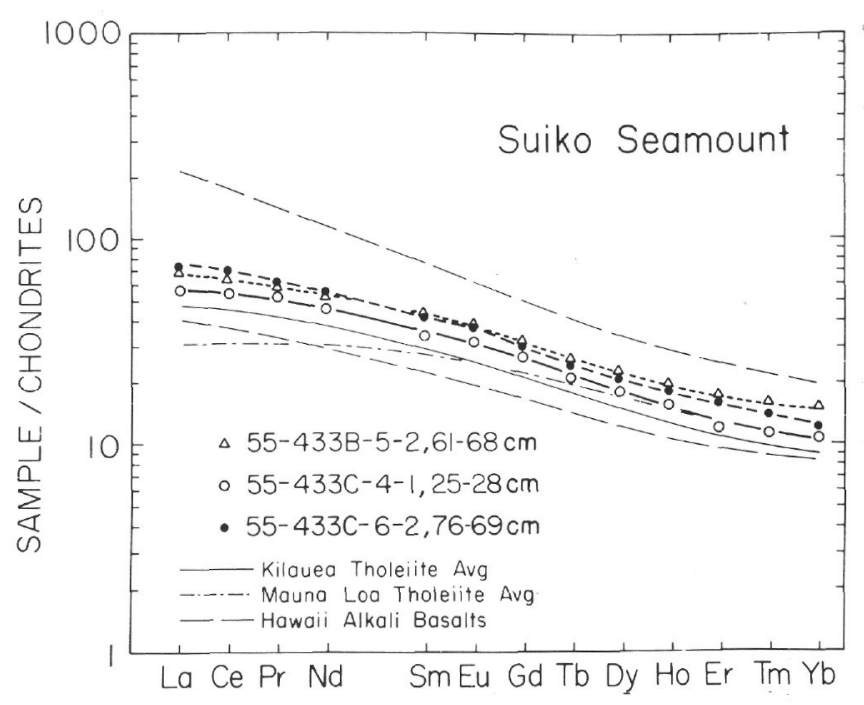

Figure 8. Normalized REE data for Suiko Seamount basalts. Hawaii data as for Figure 6.

tion involving olivine is the dominant process controlling the chemical variations in Kilauea basalts, where it takes place in shallow magma chambers (see, for example, Wright et al., 1975). Tholeiitic basalts from Suiko Seamount have the most pronounced olivine control (Figures 3a, 4a). The more evolved of these samples have $\mathrm{Al}_{2} \mathrm{O}_{3}$ abundances and $\mathrm{Mg} /\left(\mathrm{Mg}+\mathrm{Fe}^{2+}\right)$ ratios (Figure $3 \mathrm{~b}$ ) that fall within or near the compositional field for MORB glasses (Bence et al., 1979). This suggests that in the later stages of fractionation the liquid compositions experienced olivine-plagioclase and olivine-plagioclase-clinopyroxene controls. The alkaline basalts from Ōjin and Nintoku seamounts have $\mathrm{Al}_{2} \mathrm{O}_{3}$ concentrations (Figure 3a, 3b) consistent with some plagioclase accumulation. This is supported by considerations of texture. Plagioclase accumulation may have occurred through flotation in shallow magma chambers, or it may be a consequence of flow differentiation.

Slight but significant major- and trace-element differences between the sites cannot be due solely to the fractionation process. The most pronounced of these differences is in the alkali content (Table 1). Ōjin basalts have the highest total alkali content, and there is a general decrease in average $\mathrm{K}_{2} \mathrm{O}$ contents from Ōjin $(1.65$ wt. $\%)$ to Nintoku (1.24 wt. \%) to Suiko $(0.80$ wt. $\%)$. The Suiko alkali basalts are also characterized by higher $\mathrm{CaO}$ and "FeO" contents. These differences reflect either geochemically different sources or variable degrees of partial melting of a common source. Crystal fractionation at low or high pressure cannot explain these differences.

The REE and other LIL trace-element abundance distributions tend to support the hypothesis that fraction of melting and/or source-region heterogeneities are the dominant factors affecting the chemistry of the basalts from the three seamounts. The rare-earth distribution patterns suggest that garnet is an important residual phase in the source regions of both the alkalic and tho- 
leiitic basalts from the three seamounts. The differences in the REE patterns obtained at each seamount may be a consequence of slight variations in the fraction of melting, resulting in differing residual mineralogical proportions. If the alkali basalts at each seamount were generated by partial melting of a geochemically homogeneous source, the relative proportions of partial melting, as indicated by the LIL element abundances are Ōjin < Nintoku < Suiko. The progressive decrease in LIL element abundances from Ōjin to Nintoku to Suiko is in the opposite direction to what might be expected, if a common source region is evolving with time.

The tholeiitic and alkali series basalts recovered from Ōjin, Nintoku, and Suiko seamounts are generally similar in major- and trace-element chemistry to the tholeiitic and alkaline basalts from the island of Hawaii. The tholeiitic and alkaline basalts at each locality are enriched in $\mathrm{TiO}_{2}$, "FeO", and alkalis, relative to midocean ridge tholeiites. At comparable $\mathrm{Mg} /\left(\mathrm{Mg}+\mathrm{Fe}^{2+}\right)$ ratios, the Hawaiian Island and Emperor Seamount tholeiites are depleted in $\mathrm{Al}_{2} \mathrm{O}_{3}$, relative to MORBs. These major-element differences appear to reflect major chemical differences between the source regions of MORBs and intraplate island and seamount tholeiites. Variations in the percentage of partial melting of a common source, differences in the partial melting mechanism, or variable degrees of fractionation of a common parental magma cannot account for the observed differences between MORBs and the members of the island/ seamount basalt series.

The lower $\mathrm{Al}_{2} \mathrm{O}_{3}$ contents of the island and seamount tholeiites relative to MORBs may be a consequence of differing residual mineralogies. The retention of a small percentage of garnet $(<10 \%)$ in the source regions of the island tholeiites can explain both their reduced $\mathrm{Al}_{2} \mathrm{O}_{3}$ contents and their fractionated REE patterns. Garnet will be an important residual phase for relatively small degrees of partial melting ( $\leq 10$ to $15 \%$ ) under conditions of high pressure ( $\gtrsim 25 \mathrm{~kb}$ ). The higher LIL content of island tholeiites suggests that these basalts are derived from source regions relatively undepleted in these elements.

The trace-element data reported in this paper show no systematic differences from published data on basalts erupted on the island of Hawaii. If the basalts erupted along the Emperor-Hawaiian chain were generated at a single hot spot, geochemical evolution of the source with time has been insignificant. Alternatively, replenishment of the source from undepleted mantle may have occurred continually.

\section{ACKNOWLEDGMENTS}

We wish to acknowledge the assistance of P. E. Muir and J. M. G. Shelley in the Mass Spectroscopy Laboratory at Aus- tralian National University, and W. Holzwarth in the Electron Microprobe Laboratory at S.U.N.Y., Stony Brook. Leg 55 samples were made available to us through the generosity of D. A. Clague and the late E. D. Jackson.

This research was supported by NSF Grants OCE7622193A01 and OCE78-20058 (Submarine Geology and Geophysics).

\section{REFERENCES}

Bence, A. E. and Albee, A. L., 1968. Empirical correction factors for the electron microanalysis of silicates and oxides, J. Geol., v. 76, pp. 382-401.

Bence, A. E., Baylis. D. M., Bender, J. F., and Grove, T. L., in press. Controls on the major and minor element chemistry of mid-ocean ridge basalts and glasses. In Implications of Deep Drilling Results in the North Atlantic, Second Ewing Symposium.

Bence, A. E., Papike, J. J., Ayuso, R. A., 1975. Petrology of submarine basalts from the central Caribbean, J. Geophys. Res., v. 80, pp. $4775-4804$.

Erlank, A. J. and Kable, E. J. D., 1976. The significance of incompatible elements in mid-Atlantic Ridge basalts from $45^{\circ} \mathrm{N}$ with particular reference to $\mathrm{Zr} / \mathrm{Nb}$, Contrib. Mineral. Petrol., v. 54, pp. 281-291.

Frey, F. A., Bryan, W. B., Thompson, G., 1974. Atlantic Ocean floor: Geochemistry and petrology of basalts from Legs 2 and 3 of the Deep-Sea Drilling Projects, J. Geophys. Res., v. 79, pp. 5507-5527.

Jackson, E. D., 1977. Linear volcanic chains on the Pacific plate. In Sutton, G. H., Manghnani, M., Moberly, R. (Ed.), The Geophysics of the Pacific Ocean Basin and Its Margin: Am. Geophys. Union Monograph 19, pp. 319-335.

Kay, R. W. and Gast, P. W., 1973. The rare earth content and origin of alkali-rich basalts, J. Geol., v. 81, pp. 653-682.

Leeman, W. P., Mural, A. V., Ma, M.-S., Schmitt, R. A., 1977. Mineral constitution of mantle source regions for Hawaiian basalts - rare earth element evidence for mantle heterogeneity. In Dick, H. E. (Ed.), Proceedings of the AGU Chapman Conference on Partial Melting in the Earth's Upper Mantle; Oregon Dept. Geol. Mineral. Indust. Bull. 96, pp. 169-183.

Macdonald, G. A. and Katsura, T., 1964. Chemical composition of Hawaiian lavas, J. Petrol., v. 5, pp. 82-133.

Nicholls, I. A., 1974. A direct fusion method of preparing silicate glasses for energy dispersive electron microprobe analysis, Chem. Geol., v. 14, pp. 141-157.

Schilling, J,-G. and Winchester, J. W., 1969. Rare earth contribution to the origin of Hawaiian lavas, Contr. Mineral. Petrol., v. 23, pp. 27-37.

Taylor, S. R. and Gorton, M. P., 1976. Geochemical application of spark source mass spectrography - III. Element sensitivity, precision and accuracy, Geochim. Cosmochim. Acta, v. 41 , pp. $1375-1380$.

Wright, T. L., Swanson, D. A., and Duffield, W. A., 1975. Chemical compositions of Kilauea east-rift lava, 19681971, J. Petrology, v. 16, pp. 110-133. 